\title{
Retraction Note to: Loss of PDEF, a prostate-derived Ets factor is associated with aggressive phenotype of prostate cancer: Regulation of MMP 9 by PDEF
}

Thomas R. Johnson, Sweaty Koul, Binod Kumar, Lakshmipathi Khandrika, Sarah Venezia, Paul D. Maroni, Randall B. Meacham and Hari K. Koul ${ }^{*}$

Retraction Note to: Mol Cancer 9, 148 (2010) https://doi.org/10.1186/1476-4598-9-148

The Editor-in-Chief has retracted this article. After publication concerns were raised that the images above the last two bars in Fig. 4D are identified as PC3 cells, whereas in [1] the same images in Fig. 5F above the first and fourth bars are identified as DU145 cells. An investigation by the University of Colorado at Denver was unable to establish the veracity of these images as the original data were not available. The Editor-in-Chief no longer has confidence in the data presented. Hari K Koul, Paul D Maroni, Lakshmipathi Khandrika, Randall B Meacham and Binod Kumar agree with this retraction. Sweaty Koul has not responded to any correspondence from the Editor-in-Chief or Publisher about this retraction. The Editor-in-Chief was not able to obtain a current email address for Thomas R. Johnson and Sarah Venezia.
Published online: 27 August 2021

\section{Reference}

1. Johnson TR, Khandrika L, Kumar B, Venezia S, Koul S, Chandhoke R, et al. Focal adhesion kinase controls aggressive phenotype of androgenindependent prostate Cancer. Mol Cancer Res. 2008;6(10):1639-48. https:// doi.org/10.1158/1541-7786.MCR-08-0052.

* Correspondence: hari.koul@ucdenver.edu

Program in Urosciences, Division of Urology-Department of Surgery, University of Colorado Denver School of Medicine, Denver Veterans

Administrative Medical Center, and University of Colorado Comprehensive Cancer Center, Building P15 or RC2, C-317, 12700 E 19th Avenue, Aurora, CO 80045, USA

(c) The Author(s). 2021 Open Access This article is licensed under a Creative Commons Attribution 4.0 International License, which permits use, sharing, adaptation, distribution and reproduction in any medium or format, as long as you give appropriate credit to the original author(s) and the source, provide a link to the Creative Commons licence, and indicate if changes were made. The images or other third party material in this article are included in the article's Creative Commons licence, unless indicated otherwise in a credit line to the material. If material is not included in the article's Creative Commons licence and your intended use is not permitted by statutory regulation or exceeds the permitted use, you will need to obtain permission directly from the copyright holder. To view a copy of this licence, visit http://creativecommons.org/licenses/by/4.0/ The Creative Commons Public Domain Dedication waiver (http://creativecommons.org/publicdomain/zero/1.0/) applies to the data made available in this article, unless otherwise stated in a credit line to the data. 